\title{
ВПЛИВ ПЕРЕНЕСЕННЯ ВИПРОМІНЮВАННЯ НА ВІДХИЛЕННЯ ВІД РІВНОВАЖНОГО СТАНУ ЩЛЬНОЇ ЕЛЕКТРОДУГОВОЇ ПЛАЗМИ: КРИТЕРІАЛЬНИЙ ПІДХІД
}

\author{
В.А. ЖОВТЯНСЬКИЙ, Ю.І. ЛЕЛЮХ, Я.В. ТКАЧЕНКО
}

УДК 533.93, 537.523.5, 537.533 .75

(C) 2012
Інститут газу НАН України

(Вул. Дегтярівсъка, 39, Київ 03113; e-mail: zhovt@ukr. net)
Принципово оцінено роль процесів випромінювання з урахуванням його перенесення щодо відхилення від рівноважного стану щільної електродугової плазми атмосферного тиску. Задачу розглянуто на прикладі електричної дуги циліндричної форми, стабілізованої стінкою. Розв'язок отримано у варіанті критерію застосовності припущення локальної термодинамічної рівноваги з урахуванням ролі процесів перенесення випромінювання у плазмі та його втрат. Дані числового моделювання доводять наявність ефектів відхилення від рівноважного розподілу заселення між резонансними та основним енергетичними рівнями атомів міді в умовах, що моделюють стан плазми в атмосферній електричній дузі між плавкими мідними електродами.

\section{1. Роль процесів випромінювання у порушенні рівноважного стану плазми}

В абсолютній більшості публікацій з фізики плазми та газового розряду вважається, що плазма електричної дуги при тиску $p \geq 1$ атм перебуває у стані локальної термодинамічної рівноваги (ЛТР). На термінологічному рівні цьому відповідає віднесення цієї плазми до так званої термічної [1]. Припущення ЛТР дозволяє значно спростити математичний апарат для визначення властивостей плазми, оскільки всі вони в кожному елементарному об'ємі в цьому випадку є функцією тільки двох термодинамічних параметрів наприклад, температури $T$ і концентрації частинок. Зокрема заселеності збуджених рівнів плазмоутворюючих частинок визначаються рівнянням Больцмана:

$n_{k}^{0}=n_{i}^{0}\left(g_{k} / g_{i}\right) \exp \left(-\Delta E_{i k} / T\right)$ де $n$ - концентрація атомів у верхньому $k$ та нижньому $i$ станах (верхній індекс "0" вказує на рівноважне значення), $g_{k}$ і $g_{i}$ - статистичні ваги цих рівнів, $\Delta E_{i k}$ - енергія збудження.

Визначальним для рівноважної системи є принцип детальної рівноваги: кожний елементарний процес зрівноважений точно протилежним зворотним процесом $[2,3]$. Наприклад, заселенню збуджених енергетичних станів атома у зіткненнях з електронами у плазмі відповідає зустрічний процес їхньої дезактивації в непружних зіткненнях цих же частинок [4]. У цьому випадку принципу детальної рівноваги відповідає співвідношення

$n_{k}^{0} \omega_{k i}=n_{i}^{0} \omega_{i k}$

де $\omega$ - частота збудження та дезактивації атомів між цими станами. Частота $\omega_{i k}$ актів збудження становить

$\omega_{i k}=N_{e} q_{i k}\left(k T / m_{e}\right)^{1 / 2} \exp \left(-\Delta E_{i k} / k T\right)$,

де $N_{e}$ - концентрація електронів, $q_{i k}$ - середнє значення перерізу збудження, $k$ - стала Больцмана, $T$ - температура, $m_{e}$ - маса електрона. Процес можливий, якщо кінетична енергія електрона перевищує енергію збудження $\Delta E_{i k}$.

Строго кажучи, термодинамічна рівновага властива лише замкненим системам. Для електродугової плазми, яка є відкритою системою принаймні щодо втрат випромінювання, справедливість ЛТР у звичайних припущеннях відповідає тій обставині, що процеси зіткнення заселення кожного енергетичного 
стану в зіткненнях значно переважають над випромінювальними процесами їх дезактивації, іншими словами, це припущення є прийнятним тільки для щільної плазми.

Як правило, найскладніше виконати умови підтримання ЛТР для резонансних переходів плазмоутворюючих частинок. Дійсно, з рівняння стану Саха випливає, що максимум іонізації частинок певного сорту та заряду досягається при характерній температурі $T^{*} \sim 0,1 E_{i}$, де $E_{i}-$ потенціал іонізації цих частинок. 3 іншого боку, енергія збудження резонансного рівня $\Delta E_{0 r}$ для більшості газів становить $(0,7-$ $0,8) E_{i}$, а для більшості металів, які використовують у плазмових технологіях - $(0,4-0,5) E_{i}[5]$. Таким чином, при температурі $T^{*}$ у плазмі присутня відносно незначна кількість електронів, енергія яких достатня для збудження резонансного рівня з основного, враховуючи характер максвелівського розподілу їх за швидкостями (див. (3)). Навпаки - інтенсивність резонансних ліній $є$, як правило, найвищою, оскільки інтенсивність $\varepsilon$ лінії випромінювання визначається заселеністю верхнього рівня $n_{k}$ відповідного спектрального переходу

$\varepsilon=A_{k i} g_{k} n_{k} / \lambda_{k i}$

де $A_{k i}$ - імовірність спектрального переходу $\lambda_{k i}$. Для резонансного переходу при температурі $T^{*}$ ці заселеності є найбільшими, як найбільшими є і значення $A$.

У результаті незбалансованої дії цих факторів концентрація електронів $N_{e}^{*}$, при якій досягається ЛТР в оптично тонкій плазмі, (наприклад, водню), виявляється занадто великою (близько $N_{e}^{*} \sim 10^{18} \mathrm{~cm}^{-3}$ ), щоб реалізуватись у більшості практичних випадків.

Однак, як правило, в електричній дузі атмосферного тиску характерна довжина $\langle l\rangle$ пробігу резонансних фотонів у максимумі лінії випромінювання є значно меншою, ніж типовий радіус дуги. Для її оцінки можна використати співвідношення

$\langle l\rangle=\kappa_{0}^{-1}$

де $\kappa_{0}$ - коефіцієнт поглинання у центрі спектральної лінії; він визначається заселеністю нижнього рівня $n_{i}$ :

$\kappa_{0}=\left(1-g_{i} n_{k} / g_{k} n_{i}\right) p f_{i k} \lambda_{k i}^{2} n_{i} / \Delta \lambda$.

Тут $p$ - числовий коефіцієнт, $f$ - сила осцилятора для відповідного переходу, $\Delta \lambda$ - ширина контуру спектральної лінії на половинній висоті. Множник у дужках описує вимушене випромінювання, яке слід ураховувати, якщо верхній рівень є заселеним (як правило, у роботах з перенесення випромінювання раннього періоду $[4,6,7]$ він не розглядався). Якщо $\lambda$ i $\Delta \lambda$ вимірюють в нм, а $n-\mathrm{B} \mathrm{cM}^{-3}$, то числове значення $p$ у формулі (6) становить $8,19 \cdot 10^{-20}$ для контуpy Гауса i $5,63 \cdot 10^{-20}$ - для Лоренца [8]. Безрозмірна величина $f$ пропорційна імовірності переходу $(A-$ в $\mathrm{c}^{-1}$, a $\lambda-$ в нм):

$A_{k i}=6,66 \cdot 10^{13} g_{i} f_{i k} /\left(g_{k} \lambda_{k i}^{2}\right)$.

Для плазми атмосферного тиску у водні, гелії, азоті та аргоні при характерній температурі $T^{*}$ довжина пробігу резонансного випромінювання згідно з (4) становить $\langle l\rangle \sim 10^{-4}$ см, а в мідній плазмі при вмісті парів міді $1 \%-10^{-2}$ см для резонансних ліній атома міді 324,7 і 327,4 нм [5]. Їхне самопоглинання ефективно знижує роль випромінювальної дезактивації збуджених рівнів, відповідно знижуючи також поріг концентрації електронів $N_{e}^{*}$, за якого досягається ЛТР в оптично щільній однорідній плазмі. У кількісному відношенні останнє характеризується введенням ефективної ймовірності радіаційного переходу $A_{r 0}^{*}$, яка враховує самопоглинання випромінювання у плазмі:

$A_{r 0}^{*}=A_{r 0} \theta(r)$,

де $A_{r 0}$ - ймовірність резонансного радіаційного переходу, а $\theta(r)$ - виходу резонансного фотона 3 точки $r$ за межі плазми без поглинання.

Визначальний вплив резонансного переходу на стан рівноваги плазми зумовлюе поширення так званої дворівневої моделі атома з двома енергетичними рівнями - основним 1 та збудженим 2. У стаціонарному випадку баланс заселеності збудженого рівня в цій моделі можна подати у такому вигляді:

$n_{1} \omega_{12}=n_{2} \omega_{21}+n_{2} A_{21}^{*}$.

Узагалі-то, відхилення від рівноважного значення зручно описувати на основі відносної заселеності рівнів [4]:

$y_{k}=n_{k} / n_{k}^{0}$.

Підставляючи в (9) вирази (2) і (10), одержуємо базове співвідношення

$y_{1}=y_{2}\left(1+A_{21}^{*} / \omega_{21}\right)$.

Очевидно, що критерієм відносної рівноваги двох станів (тобто $y_{k} \approx y_{l}$ ) або $y_{2} \approx y_{1} \approx 1$ у випадку дворівневої моделі є нерівність

$A_{21}^{*} / \omega_{21} \ll 1$ 
інакше кажучи, переважання процесів зіткнень, які відновлюють рівновагу, над радіаційними, що їі порушують.

Далі ми поширюємо ідеологію дворівневої моделі на розгляд енергетичного переходу не тільки з резонансного рівня на основний, але й на метастабільний, розглядаючи, таким чином, фактично трирівневу систему. Проте в рамках критеріального підходу, де досліджуються незначні відхилення від рівноважного стану, це цілком можливо. Різниця тільки полягає в тому, що в цьому випадку заселеність нижнього рівня для спектральних переходів між резонансними та метастабільними енергетичними рівнями визначається 3 розподілу Больцмана (1), оскільки у прийнятих вище припущеннях відсутня фізична причина для їх нерівноважності. Надалі, якщо ми конкретно розглядаємо трирівневу систему, то вживаємо відповідні індекси "0", " $m$ " і " $r$ ", а якщо загальну дворівневу - то цифрові індекси "1" i "2".

Не можна вважати, що вплив випромінювальних переходів між резонансними та метастабільними рівнями матиме вирішальний ефект з точки зору відхилень системи від стану ЛТР. Проте відповідні їм спектральні лінії лежать у видимій області спектра і $€$ досить доступними для дослідницьких цілей. Зокрема, одна з цих ліній, 510,5 нм - одна з найбільш популярних в оптичній діагностиці мідної електродугової плазми $[5,9]$.

Критеріальні підходи щодо встановлення ЛТР у плазмі з точки зору втрат випромінювання були введені ще Г. Грімом [10 (гл. 6)]. Для того, щоб ЛТР виконувалась з точністю 10\%, швидкості процесів, поданих у відношенні (12), повинні відрізнятися на порядок.

Фактично все, що обговорювалось вище стосовно ролі самопоглинання випромінювання відноситься до температурно-однорідної плазми. Однак у випадку неоднорідної плазми самопоглинання випромінювання може привести до протилежного ефекту. Дійсно, випромінювання, яке надійшло від більш гарячих областей плазми та поглинулось у деякій точці спостереження $r>0$, може не тільки компенсувати втрати енергї випромінюванням, але й зумовити зворотний ефект: перевищення у цій точці заселення збудженого рівня по відношенню до рівноважного. Його межею є рівень заселення, що відповідає значенню температури на осі дуги.

Експериментально нерівноважність плазми у вільно підтримуваній електричній дузі між плавкими мідними електродами в атмосфері в результаті перенесення резонансного випромінювання атомів міді спо- стерігали у роботі [9]. Пізніше було запропоновано просту модель такої нерівноважності, яка відповідає заселенню резонансного рівня атома міді вздовж радіуса дуги з температурою, характерною для осьової області дуги (що відповідає перезаселенню резонансного рівня на периферії дуги, де локальна температура є меншою, ніж на осі) [11]. Його аналогом на рівні макросвіту є ефект каміна - нагрівання предметів в умовах зовсім холодної кімнати внаслідок поглинання теплового випромінювання [12].

Як випливає 3 вищенаведених матеріалів (див. формули (3), (4) і супровідний текст), нерезонансне випромінювання не виступає суттєвим фактором щодо ефектів, пов'язаних з перенесенням випромінювання. Якщо продовжити аналогії на рівні макросвіту, то для випромінювання з вищих рівнів найближчим є ефект свічки: світить та не гріє.

У цьому припущенні, як було показано, може досягатися ефект "просвітлення" каналу електричної дуги - зменшення його опору протіканню електричного струму [11-13]. Фізичною причиною останнього є ефективне зменшення потенціалу іонізації плазмоутворюючих атомів на периферії дуги в результаті перезаселення в цій області резонансних рівнів атомів. Таким чином, для подальших практичних застосувань важливо строго враховувати явище перенесення випромінювання у плазмі та його вплив на відхилення стану плазми від рівноважного. Розвитку цього напрямку дослідження плазми електричної дуги присвячено дану роботу.

Нижче наведено розрахунки, що дозволяють принципово оцінити роль процесів випромінювання щодо відхилення від рівноважного стану щільної низькотемпературної плазми. На цьому етапі розгляду проблеми розв'язок задачі знаходиться у варіанті критерію застосовності ЛТР з урахуванням ролі процесів випромінювання у плазмі та його втрат. Така постановка дещо спрощує задачу, оскільки подібно до [10] дозволяє обмежитись припущенням про рівноважний стан плазми при її розв'язку.

Об'єктивним недоліком цього підходу є індикативний характер отримуваного результату, який констатує стан відхилення від рівноважного стану плазми, проте не дозволяє кількісно визначити рівень цього відхилення.

\section{2. Постановка задачі та метод розв'язку}

Урахування процесів перенесення випромінювання, на відміну від перенесення речовини, термодинамічні параметри якої змінюються неістотно на довжинах 
порядку вільного пробігу частинок цієї речовини, викликає значні складнощі, зумовлені різкою залежністю довжини пробігу фотонів від частоти. Дійсно, вираз (5) записаний для центра спектральної лінії з частотою $\nu_{0}$. Проте, для частот $\nu$ за їі межами локальні значення коефіцієнта поглинання $\kappa=f\left(\nu-\nu_{0}\right)$ пробігають всю область значень $0<\kappa<\kappa_{0}$. Їм відповідає зростання локальних значень $\langle l\rangle$ згідно 3 (5). Тому можливим є значний взаємний вплив навіть доволі віддалених елементарних об'ємів плазми чи навіть поглинання випромінювання за межами власне каналу дуги, зважаючи на те, що знайдуться значення $\langle l\rangle$, які є розмірні з відстанню між ними (ураховуючи, звичайно, фактор тілесного кута, в якому поширюється згадане випромінювання або, іншими словами, відстані між згаданими елементарними об'ємами). Власне, таке самопоглинання стало першопричиною перенаселення й збуджених рівнів атомів міді за межами каналу дуги в експерименті [9].

Неможливість введення характерної довжини пробігу фотонів не припускає використання дифузійного наближення, а для адекватного математичного опису процесів перенесення випромінювання недостатньо диференціальних співвідношень. Тут доводиться переходити до інтегральних рівнянь, що враховують взаємний вплив процесів у всьому об'ємі плазми.

Динаміку заселеності резонансного рівня атома $n_{2}(r, t)$ у дворівневій моделі, яка визначається переходами на основний стан та 3 нього, ураховуючи також процеси радіаційного перенесення збудження, можна подати так [4]:

$$
\begin{aligned}
& \frac{\partial n_{2}(r, t)}{\partial t}=-n_{2}(r, t) A_{21}-n_{2}(r, t) \omega_{21}+ \\
& +n_{1} \omega_{12}+\int_{V} n_{2}\left(r^{\prime}, t\right) A_{21} K\left(\left|r-r^{\prime}\right|\right) d r^{\prime} .
\end{aligned}
$$

Тут інтегральний член ураховує радіаційне перенесення випромінювання, а ядро $K\left(\left|r-r^{\prime}\right|\right)$ виступає як ймовірність того, що резонансний фотон, випромінений із довільної точки $r^{\prime}$, поглинеться в об'ємі 3 координатою $r$ :

$K(\rho)=-\frac{1}{4 \pi \rho^{2}} \frac{d f(\rho)}{d \rho}, \quad \rho \equiv\left|r-r^{\prime}\right|$.

Множник $\left(4 \pi \rho^{2}\right)^{-1}$ виділяє ті фотони, які поширюються від $d r^{\prime}$ у напрямку $d r$ (іншими словами - визначає тілесний кут), а $f(\rho)$ - ймовірність проходження частинкою відстані $\rho$ без поглинання та розсіювання:

$f(\rho)=\int \varepsilon_{\nu} \exp \left(-k_{\nu} \rho\right) d \nu$ де $\varepsilon_{\nu}$ - нормований на одиницю розподіл за частотами фотонів, який визначається формою контуру лінії випромінювання, а інтенсивність останньої - заселеністю верхнього рівня (цьому факту відповідає наявність множника $n_{2}$ у підінтегральному виразі (13), $k_{\nu}$ - спектральний коефіцієнт поглинання. Конкретний вигляд $f(\rho)$ залежить від форми ліній поглинання та випромінювання, тобто від $k_{\nu}, \varepsilon_{\nu}$. Однак, з урахуванням згаданих вище обставин, ця функція не є експоненціальною - як це відбувається у процесах перенесення речовини - й спадає зі зростанням $\rho$ суттєво повільніше [4]. У (14) множник $d f(\rho) / d \rho$ ураховує ослаблення пучка фотонів на шляху від $r^{\prime}$ до $r$ та ймовірність поглинання в $d r$ тих фотонів, що до нього долетіли.

Слід наголосити, що вираз для $f(\rho)$, записаний у формі (15), є значним спрощенням для плазмового середовища, оскільки він, фактично, передбачає постійність спектрального коефіцієнта поглинання $k_{\nu}$. По суті ж, особливо для неоднорідної електродугової плазми, він є функцією від радіальної координати.

Виконавши операцію диференціювання в (14), одержимо

$K(\rho)=\left(4 \pi \rho^{2}\right)^{-1} \int \varepsilon_{\nu} k_{\nu} \exp \left(-k_{\nu} \rho\right) d v$.

Хоча $K(\rho)$ згідно з асимптотичною поведінкою ймовірності $f(\rho)$ спадає повільно, інтеграл від $K(\rho)$, взятий по нескінченному об'єму, дорівнює одиниці. Останне випливає з фізичного змісту задачі.

Для випадку стаціонарних процесів рівняння (13) зручно записати з урахуванням (10) для приведеної заселеності збудженого стану:

$y_{2}(r)=(1+\beta)^{-1} \int_{V} y_{2}\left(r^{\prime}\right) K\left(\left|r-r^{\prime}\right|\right) d r^{\prime}+\beta /(1+\beta)$.

Тут уведено позначення

$\beta=\omega_{21} / A_{21}$

і використано співвідношення між $\omega_{12}, \omega_{21}$, яке випливає 3 принципу детальної рівноваги (2); прийнято також, що значення $n_{2}^{0}$ не залежить від координат. Останнє є істотним спрощенням задачі, що розглядається, але й доволі серйозним наближенням. Воно, фактично, полягає в тому, що значення $n_{1} \approx N_{a} \sim$ $T^{-1}$, які визначаються з рівняння для парціального тиску парів міді:

$\left[N_{a}+\left(1+x_{\mathrm{Cu}}\right) N_{e}\right] k T=x_{\mathrm{Cu}} p$, 
де $p$ - атмосферний тиск, а $x_{\mathrm{Cu}}-$ вміст мідної пари у плазмоутворюючій суміші, замінюється співвідношенням, яке відповідає рівнянню Больцмана $n_{1} \sim$ $n_{2}^{0} \exp \left(\Delta E_{12} / T\right)=$ const. Проте його прийнятність для наближених обчислень випливає з теореми про середне для визначеного інтеграла.

Пошук аналітичного розв'язку рівняння радіаційного перенесення є складною задачею. В тих рідкісних випадках, коли навіть вдається отримати аналітичний розв'язок, він виявляється досить громіздким [6]. Тому особливе значення мають чисельні методи розв'язку подібних задач.

Л.М. Біберманом був запропонований [7] простий наближений метод розв'язку рівняння (17). При цьому вважається, що навіть при сильній залежності $n_{2}(r)$ від радіальної координати величина, яка характеризує локальне порушення рівноваги, може змінюватись досить слабо. Це є ще одним наближенням, проте воно дає можливість винести $y_{2}\left(r^{\prime}\right)$ за знак інтеграла, приписавши цій величині значення $y_{2}(r)$ :

$y_{2}\left(r^{\prime}\right)=y_{2}(r)$.

Тоді (17) перетворюється на алгебраїчне рівняння, 3 якого можна отримати такі наближені результати (позначені значком "тильда"):

$\tilde{y}_{2}(r)=\frac{\beta(r)}{\theta(r)+\beta(r)}$,

$\tilde{n}_{2}(r)=n_{1} \omega_{12} /\left(\omega_{21}+A_{21} \theta(r)\right)$

$\theta(r)=1-\int_{V} K\left(\left|r-r^{\prime}\right|\right) d V^{\prime}$

Останній з цих виразів відповідає ймовірності вильоту фотона з точки $r$ за межі плазми без поглинання, введеній у співвідношенні (8). Тут інтегрування здійснюється по всьому об'єму дуги, а його результат визначає, яка частина випромінювання поглинулась у цьому об'ємі. Таким чином, вплив скінчених значень оптичної щільності враховується ефективною ймовірністю спонтанного випромінювання $A_{21}^{*}$; $з$ їі зменшенням зростає обернена величина $\tau_{\text {еф }}=\left(A_{21}^{*}\right)^{-1}$, яку називають ефективним часом життя збудженого рівня. Тому це наближення часто називають методом ефективного часу життя.

Цей метод було успішно використано (див. [4]) для розв'язку низки задач у випадку температурнооднорідної плазми, для якого є справедливими вирази
(15) i, відповідно, (16). У цьому варіанті $0 \leq \theta(r)<1$ і цілком відповідає категорії імовірності.

Якщо залежність від координат коефіцієнта поглинання $\kappa_{\nu}$ пов'язана лише 3 кількістю поглинаючих атомів за умов незмінності контурів спектральних ліній, тобто $\kappa_{\nu}=a n_{1}(r)$, де $a$ - коефіцієнт пропорційності, то в цьому випадку можна ввести у розгляд оптичну товщу для її використання в рівнянні (13):

$\int_{\mathbf{r}}^{\mathrm{r}^{\prime}} k_{\nu}\left(\mathrm{r}^{\prime \prime}\right) d r^{\prime \prime}=t^{\prime}-t, \quad d t=a n_{1}(\bar{r}) d \bar{r}$

як нову систему координат, в якій, зокрема, залишається справедливим метод ефективного часу. Проте ця задача не дозволяє виявляти специфічні ефекти у плазмі, зумовлені згаданою вище розбіжністю характерних довжин пробігу резонансного випромінювання.

На відміну від цього ми шукаємо розв'язок задачі (13) у варіанті неоднорідного середовища. При цьому залишається справедливим загальний вигляд розв'язку (21), проте у виразі (21b), розглядаємо таке ядро $K\left(r^{\prime}, r\right)$, яке включає інтегрування щодо впливу самопоглинання уздовж кожного променя:

$K\left(r^{\prime}, r\right)=\frac{1}{4 \pi} \int_{0}^{\infty} \frac{k_{\nu}\left(r^{\prime}\right) \varepsilon_{\nu}\left(r^{\prime}\right)}{\left|\mathrm{r}-\mathrm{r}^{\prime}\right|^{2}} \exp \left[-\int_{\mathbf{r}}^{\mathbf{r}^{\prime}} k_{\nu}\left(\mathrm{r}^{\prime \prime}\right) d \mathrm{l}\right] d \nu$.

Тут у показнику експоненти фігурує контурний інтеграл уздовж променя, що з'єднує точки з координатами $r$ i $r^{\prime}$. Вважаємо також, що плазма зосереджена в довгому циліндричному об'ємі радіуса $R$.

Тепер, з огляду на залежність коефіцієнта поглинання в лінії в інтегральному ядрі (23) від температури, яка є функцією координат, величині $\theta(r)$, на відміну від [4] не надається простого ймовірнісного змісту, і вона може мати як додатне, так і від'ємне значення [6]. Тут цей параметр ураховує вплив двох імовірнісних процесів, які мають, проте, протилежний ефект на заселеність енергетичного рівня в локальному об'ємі плазми: зменшення заселеності внаслідок втрат випромінювання з цього об'єму і збільшення - внаслідок поглинання випромінювання з інших областей плазми, якщо вони мають вищу температуру. Проте вираз $A_{21} \theta(r)$ все одно дає наближене значення дивергенції потоку фотонів у точці.

Із виразу (21a) випливає, що умовою близькості $y_{2}(r)$ до одиниці, тобто внутрішньо несуперечним 3 припущенням (20) критерієм виконання ЛТР, є

$|\theta(r) / \beta(r)| \ll 1$. 
Згідно з [6] ця умова ЛТР даватиме правильний результат, якщо вона виконується в усьому об'ємі, зайнятому плазмою. Зважаючи на співвідношення (8) і (18), критерій (24) є еквівалентним узагальненням умови існування ЛТР у плазмі з урахуванням тільки втрат на випромінювання (12) у такій мірі, в якій можна вважати еквівалентними за змістом значення $\theta(r)$ у випадках втрат випромінювання та його перенесення.

Для знаходження чисельного значення інтеграла у виразі (21b) зручно перейти до локальної сферичної системи координат, пов'язаної з точкою спостереження $r$ :

$I=\frac{1}{4 \pi} \int_{0}^{\infty} \iiint_{V} \frac{k_{\nu}\left(r^{\prime}\right) \varepsilon_{\nu}\left(r^{\prime}\right)}{\left|\mathrm{r}-\mathrm{r}^{\prime}\right|^{2}} \exp \left[-\int_{\mathrm{r}}^{\mathrm{r}^{\prime}} k_{\nu}\left(\mathrm{r}^{\prime \prime}\right) d \mathrm{l}\right] d V^{\prime} d \nu=$

$$
=\frac{1}{4 \pi} \int_{0}^{\infty} \int_{0}^{2 \pi} \int_{0}^{\pi} \int_{0}^{R(\varphi)} \frac{k_{\nu}(\rho) \varepsilon_{\nu}(\rho)}{\rho^{2}} \times
$$

$\times \exp \left[-\int_{0}^{\rho} k_{\nu}(t) d t\right] \rho^{2} \sin (\theta) d \rho d \theta d \varphi d \nu$

де $I=\int_{V} K\left(r^{\prime}, r\right) d V^{\prime}, \rho=\left|\mathbf{r}-\mathbf{r}^{\prime}\right|, 0 \leq \rho<\infty$. Виходячи із симетрії задачі, розширимо межі інтегрування по частоті та виконаємо заміну змінних $\omega=$ $\left(\nu-\nu_{0}\right) / \Delta \nu(r)$ :

$I=\frac{1}{\pi} \int_{-\infty}^{\infty} \int_{0}^{\pi} \int_{0}^{\pi / 2} \int_{0}^{R(\varphi)} k_{\nu}(\rho) \varepsilon_{\nu}(\rho) \times$

$\times \exp \left[-\int_{0}^{\rho} k_{\nu}(t) d t\right] \sin (\theta) d \rho d \theta d \varphi d \omega$.

Послідовною заміною змінних $\rho=\rho^{\prime} / \sin (\theta) ; \rho^{\prime}=$ $\rho^{\prime \prime} / \sin (\theta)$ цей інтеграл приводиться до вигляду

$$
\begin{aligned}
& I=\frac{1}{\pi} \int_{-\infty}^{\infty} \int_{0}^{\pi} \int_{0}^{\pi / 2} \int_{0}^{r_{0}(\varphi)} k_{\nu}(\rho) \varepsilon_{\nu}(\rho) \times \\
& \times \frac{\exp \left[-\int_{0}^{\rho^{\prime \prime}} k_{\nu}(t) d t / \sin ^{2}(\theta)\right]}{\sin (\theta)} d \rho^{\prime \prime} d \theta d \varphi d \omega,
\end{aligned}
$$

де $r_{0}(\varphi)$ знаходиться зі співвідношення $R^{2}=r^{2}+$ $r_{0}^{2}(\varphi)-2 r r_{0}(\varphi) \cos (\pi-\varphi), R-$ радіус дуги. По суті, $r_{0}(\varphi)$ - проекція радіуса вектора, що виходить 3 точки $r$ і пробігає внутрішню поверхню циліндра, на полярну площину $(\theta=\pi / 2)$. 3 огляду на інтегральне представлення функції Бесселя третього роду уявного аргументу (функції Макдональда) маємо

$\int_{0}^{\pi / 2} \frac{\exp \left[-z / \sin ^{2}(\theta)\right]}{\sin (\theta)} d \theta=\frac{1}{2} \exp \left(-\frac{z}{2}\right) K_{0}\left(\frac{z}{2}\right)$

остаточно одержимо

$I=\frac{1}{2 \pi} \int_{-\infty}^{\infty} \int_{0}^{\pi} \int_{0}^{r_{0}(\varphi)} k_{\nu}(\rho) \varepsilon_{\nu}(\rho) \times$
$\times \exp \left(-\frac{Z}{2}\right) K_{0}\left(\frac{Z}{2}\right) d \rho^{\prime \prime} d \varphi d \omega$,

де

$Z=\int_{0}^{\rho^{\prime \prime}} k_{\nu}(t) d t$

Ураховуючи необмеженість функції Макдональда в околі нуля, для інтегрування по приведеному радіусу використовувалось асимптотичне представлення функції Макдональда. А саме, знаходився інтеграл від різниці функції $K_{0}(z)$ та їі асимптотичного представлення $K_{0}(t) \approx-\ln \left(\frac{t}{2}\right)-\frac{\gamma}{2}$, де $\gamma-$ стала Ейлера. Оскільки останній інтеграл береться у квадратурах в околі нуля, значення інтеграла $I$ з рівняння (28) відновлювалось як сума обчисленого значення різниці функцій і аналітичного значення інтеграла від асимптоти. Для інтегрування застосовувався метод трапецій на рівномірній сітці.

\section{3. Спектральні характеристики плазми}

У таблиці наведено перелік спектральних ліній атома міді, випромінюваних з обох резонансних рівнів $E_{k}=3,79$ eB i $E_{i}=3,82 \mathrm{eB}$ та їх спектроскопічні параметри. Частина цих ліній у ролі нижнього рівня спектрального переходу має основний рівень, частина - метастабільні рівні $E_{i}=1,39 \mathrm{eB}$ і $E_{i}=1,64 \mathrm{eB}$. Для принципової оцінки ролі ефектів перенесення випромінювання щодо відхилення плазми від стану ЛТР, дослідження проводяться по відношенню до пари таких спектральних ліній 327,3 нм та 510,5 нм. У якісному відношенні результати цих досліджень можуть 
бути поширеними і на інші групи резонансних ліній, оскільки сили осциляторів у них істотно не відрізняються між собою.

В електричній дузі температура змінюється в широкій області - від плазмової до температури внутрішньої поверхні стабілізуючої стінки або до нормальних умов, якщо дуга підтримується в атмосферному повітрі. Відповідно, уздовж радіуса дуги є істотно розбіжними локальні випромінювальні (4) та поглинальні (6) властивості плазми, а також переважаючими ті чи інші механізми розширення спектральних ліній. Характерними для цих механізмів є дві основні групи контурів спектральних ліній [8]: Гауса (він відповідає ефекту Допплера)

$\varepsilon_{\nu}(r)=\varepsilon_{0}^{\mathrm{D}}(r) p \exp \left[-\left(\Delta \nu / \Delta \nu^{\mathrm{D}}(r)\right)^{2}\right]$,

$\kappa_{\nu}(r)=\kappa_{0}^{\mathrm{D}}(r) \exp \left[-\left(\Delta \nu / \Delta \nu^{\mathrm{D}}(r)\right)^{2}\right]$

та дисперсійний (або Лоренца):

$\varepsilon_{\nu}(r)=\varepsilon_{0}^{\mathrm{L}}(r) p\left[1+\left(\Delta \nu / \Delta \nu^{\mathrm{L}}(r)\right)^{2}\right]^{-1}$,

$\kappa_{\nu}(r)=\kappa_{0}^{\mathrm{L}}(r)\left[1+\left(\Delta \nu / \Delta \nu^{\mathrm{L}}(r)\right)^{2}\right]^{-1}$,

де $\Delta \nu=\nu-\nu_{0}$, а $\varepsilon_{0}^{\mathrm{L}, \mathrm{D}}(r)$ i $k_{0}^{\mathrm{L}, \mathrm{D}}(r)-$ значення випромінювальної здатності та коефіцієнта поглинання у центрі лінії; $\Delta \nu^{\mathrm{L}, \mathrm{D}}(r)$ - ширини ліній випромінювання та поглинання для контурів Лоренца та Гауса відповідно. Значення коефіцієнта $p$ у формулах (30а) i (31a) визначається з умови їх нормування до значення (4) при інтегруванні по частотах і неістотно відрізняються між собою для різних видів контурів; саме тому розрізняються також значення $p$ у виразах для $k_{0}^{\mathrm{L}, \mathrm{D}}(r)$ згідно з $(6)$.

$\mathrm{У}$ практичній спектроскопії, зазвичай, використовують шкалу довжин хвиль випромінювання, для ширини ліній в якій справедливим є співвідношення

$\Delta \lambda=\left(c / \nu^{2}\right) \Delta \nu$

Резонансні спектральні лінії атома міді та їх спектроскопічні параметри

\begin{tabular}{c|cc|c|c|c|c|c}
\hline Лінія, нм & $E_{k}, \mathrm{eB}$ & $g_{k}$ & $E_{i}, \mathrm{eB}$ & $g_{i}$ & $\left.\begin{array}{c}\Delta \lambda_{s}^{*}, \text { нм } \\
\left(\text { при } N_{e}=10^{17} \mathrm{~cm}^{-3}\right)\end{array}\right]$ & $f$ \\
\hline 324,7 & 3,82 & 4 & 0 & 2 & & 0,430 \\
510,5 & 3,82 & 4 & 1,39 & 6 & 0,021 & 0,0051 \\
570,0 & 3,82 & 4 & 1,64 & 4 & 0,026 & 0,0011 \\
327,3 & 3,79 & 2 & 0 & 2 & & 0,220 \\
578,2 & 3,79 & 2 & 1,64 & 4 & 0,027 & 0,0042 \\
\hline
\end{tabular}

Контур Допплера визначається тепловим рухом атомів. Його ширина

$\Delta \lambda^{\mathrm{D}}=7,16 \cdot 10^{-7} \lambda_{0} \sqrt{T / \mu}$,

де $\mu$ - атомна вага, $T$ - температура, К. Для $\mu \approx 64$ та $\lambda_{0}=500$ нм $\Delta \lambda^{\mathrm{D}}$ становить $\sim 0,77 \cdot 10^{-3}$ нм при $T=$ $300 \mathrm{~K} \mathrm{i} \sim 3,7 \cdot 10^{-3}$ нм при $T=7 \cdot 10^{3} \mathrm{~K}$.

Контур Лоренца спектральної лінії описує як природне розширення лініі, так і внаслідок процесів зіткнення. Перше з них зумовлюється кінцевим часом життя $\tau_{k}$ i $\tau_{i}$ енергетичних станів атома, між яким випромінюється спектральна лінія. Для кожної з ліній, які випромінюються з резонансних рівнів, цей час $\tau_{r}$ визначається сумою ймовірностей спонтанних переходів з даного резонансного рівня на основний та метастабільні (якщо їх кілька) рівні:

$\tau_{r}^{-1}=\tau_{r 0}^{-1}+\tau_{r m 1}^{-1}+\tau_{r m 2}^{-1}+\ldots=A_{r 0}+A_{r m 1}+A_{r m 2+\ldots}$,

а відповідне розширення лінії як

$\Delta \lambda_{n}^{L}=\lambda_{0}^{2} /\left(2 \pi \tau_{r} c\right)=\left(A_{r 0}+A_{r m 1}+A_{r m 2+\ldots}\right) \lambda_{0}^{2} /(2 \pi c)$.

Для спектральних ліній 510,5 і 324,7 нм, які випромінюються із одного з резонансних рівнів атома міді $E_{r}=3,82 \mathrm{eB}$ (див. таблицю), $\Delta \lambda_{n}^{L}$ становить $0,5 \cdot 10^{-5}$ нм, тобто вона на один-два порядки менша, ніж допплерівська ширина.

Розширення спектральних ліній внаслідок процесів зіткнення зумовлюється порушеннями їх монохроматичності в результаті зіткнень випромінюючої частинки з нейтральною або зарядженою компонентою плазми. У першому випадку [8]:

$\Delta \lambda_{g}^{L}=6,6 \cdot 10^{5} \sigma^{2} p \lambda_{0}^{2}(\mu T)^{-1 / 2}$,

де $\sigma^{2}$ - ефективний переріз зіткнень $\left(\mathrm{cm}^{2}\right), p$ - тиск (мм рт. ст.), $\lambda_{0}-$ в нм. При тиску $p=1$ атм, $\sigma=5 \cdot 10^{-8}$ см, $\mu \approx 30, T=1000 \mathrm{~K}, \Delta \lambda_{g}^{L}$ становить $\sim 2 \cdot 10^{-3} \mathrm{Hм}$, тобто є значно більшою, ніж природна, і порівняною 3 допплерівською шириною при її найбільшому значенні.

Насамкінець, найбільшим ефектом щодо розширення ліній внаслідок процесів зіткнення, якщо його відносити до концентрації частинок, що зумовлюють зіткнення, є штарківський механізм [14]. У цьому випадку у ролі параметрів розширення $\Delta \lambda_{s}$ резонансних ліній атома міді, нижній рівень яких є метастабільним, ми зупинились на даних Р. і Н. Коневичів [15] 
(див. таблицю). У свій час [16] ретельно проаналізовано сукупність публікацій щодо цього параметра для іншої спектральної лінії, яка широко застосовується в діагностиці мідної плазми - 515,3 нм. На основі порівняння доступного масиву даних (які характеризуються розбіжністю результатів на порядок величини) з власними експериментальними результатами ми зупинились тоді на даних [15] і використовуємо їх тут і для лінії 510,5 нм як такі, що отримані на єдиній методологічній основі. Вони нормалізовані до величини концентрації електронів у плазмі $N_{e}=10^{17} \mathrm{~cm}^{-3}$; їх реальний ефект можна оцінити $з$ виразу

$\Delta \lambda_{s}^{L}=10^{-17} N_{e} \Delta \lambda_{s}^{*}$,

де $N_{e}-$ в $\mathrm{cm}^{3}$, а $\Delta \lambda$ - в нм. Інші дані залучено з довідника [17]. Слід наголосити, що чим глибше у структуpi атома лежать енергетичні рівні, тим більше вони екрановані від впливу зовнішніх електричних полів i тим меншим є для них ефект штарківського розширення. Для ліній, які випромінюються з верхніх збуджених станів атома міді, параметри розширення $\Delta \lambda_{s}^{*} \in$ на порядок більшими [5]; навпаки, для резонансних ліній, що мають нижнім переходом основний стан, як правило, обмежуються допплерівським механізмом розширення ліній.

Результат сумісної дії кількох механізмів розширення дисперсійного характеру теж характеризується контуром Лоренца, загальна ширина якого визначається сумою окремих складових:

$\Delta \lambda^{L}=\Delta \lambda_{n}^{L}+\Delta \lambda_{g}^{L}+\Delta \lambda_{s}^{L}$.

Результат сумісної дії механізмів розширення, один з яких описується контуром Гауса, а інший - Лоренца, визначається операцією згортки $[8,14]$ - це так званий контур Фойгта (який має спеціальне традиційне позначення $H)$ :

$H(a, u)=\frac{a}{\pi} \int_{-\infty}^{+\infty} \frac{\exp \left(-y^{2}\right)}{a^{2}+(u-y)^{2}} d y$

$a=(\ln 2)^{1 / 2} \Delta \nu^{\mathrm{L}} / \Delta \nu^{\mathrm{D}}$,

$u=2(\ln 2)^{1 / 2}\left(\nu-\nu_{0}\right) / \Delta \nu^{\mathrm{D}}$.

Особливості цього контуру досить детально висвітлені в науковій літературі (див., наприклад, [8 (с. 15)]); найбільш характерна полягає в тому, що його центральна частина (в області максимуму) відповідає переважно контуру Допплера, а в області "крил" - контуру Лоренца. В усіх числових розрахунках щоразу враховувався інтегральний вплив факторів розширення спектральних ліній відповідно до останнього співвідношення.

\section{4. Моделювання властивостей електричної дуги}

Для проведення розрахунків було використано температурний профіль, отриманий з розв'язку в одновимірному наближенні рівняння балансу енергії для циліндричної дуги, стабілізованої стінками (рівняння Еленбааса-Гелера) [18, 19]:

$\frac{1}{r} \frac{d}{d r}\left(r \frac{d S}{d r}\right)+\sigma E^{2}=0, \quad S=\int_{0}^{T} \lambda(T) d T$,

де $r$ - радіальна координата, $\sigma(T)$ - коефіцієнт електропровідності, $E$ - напруженість електричного поля, а $S$ - тепловий потенціал $(\lambda(T)$ - коефіцієнт теплопровідності). Граничними умовами $є$ :

$d s / d r_{(r=0)}=0 ; \quad S_{(r=r w)}=S_{w}$,

де $S_{w}$ характеризує температуру $T_{w}$ деякої охолоджуючої квазістінки. Її введення дозволяє моделювати дугу у припущенні одновимірної осесиметричної задачі [20].

Числовий розв'язок нелінійної крайової задачі (40), (41) знаходимо методом продовження по параметру [21]. Лінеаризоване диференціальне рівняння другого порядку на кожному кроці по параметру розв'язується методом зведення граничної задачі до послідовності задач Коші, а вони, у свою чергу - методом Дормана-Прінса [22] п'ятого порядку точності. Електричний струм і радіус поглинаючої квазістінки приймаються заданими. Як перше наближення використаний аналітичний розв'язок у припущенні квазіканалової моделі електричної дуги $[11,18]$.

Електро- та теплопровідність мідно-азотної суміші апроксимується згідно з $[11,23]$ :

$\sigma=\sigma_{0} S^{n_{\sigma}}, \quad \lambda=\lambda_{w}\left(T / T_{w}\right)^{n_{\lambda}}$.

При $x_{\mathrm{Cu}}=1 \%$ коефіцієнти апроксимації становлять: $\sigma_{0}=5,9 \cdot 10^{-8}\left(\mathrm{BT} \cdot \mathrm{M}^{k \sigma} /\left(\mathrm{OM}_{\mathrm{M}} \cdot \mathrm{M}\right), n_{\sigma}=17 / 7, n_{\lambda}=5 / 2\right.$, $\lambda_{w}=0,066 \mathrm{BT} /(\mathrm{M} \cdot \mathrm{K})$ при $T_{w}=1000 \mathrm{~K}$.

Ураховуючи оцінювальний характер розрахунків, стан плазми описується рівнянням Саха для першої кратності іонізації:

$\frac{N_{e}^{2}}{N_{a}}=2\left(\frac{2 \pi m_{e} k T}{h^{2}}\right)^{3 / 2} \frac{\Sigma_{i}}{\Sigma_{a}} \exp \left(-\frac{E_{i}}{k T}\right)$, 


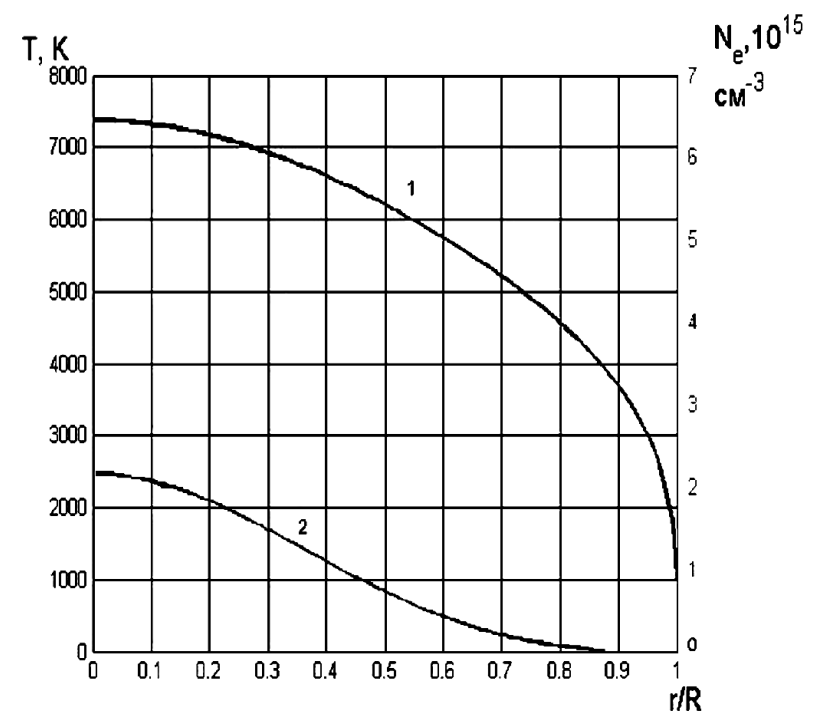

Рис. 1. Радіальний розподіл температури (крива 1) та концентрації електронів (крива 2) в електричній дузі з вмістом міді $x_{\mathrm{Cu}}=1 \%$

де $\Sigma_{a}, \Sigma_{i}$ - статистичні суми для атома та іона, $E_{i}=$ 7,73 еВ - потенціал іонізації атома міді. Воно доповнюється рівнянням для парціального тиску парів міді (19), яке ураховує, що повітряну компоненту приймають, фактично, інертною.

Для числового інтегрування внутрішнього інтеграла в контурному інтегралі (29), а також для визначення контуру Фойгта спектральних ліній (39) застосовано метод трапецій. При цьому функціональна залежність температури від радіуса визначається для точок інтегрування лінійною інтерполяцією за знайденим із розв'язку задачі (40), (41) температурним профілем.

\section{5. Результати обчислень}

Числові розрахунки виконували для атмосферної електричної дуги, що підтримується між плавкими мідними електродами при розрядному струмі 30 А. Радіус охолоджуючої квазістінки $R_{w}=3$ мм, а їі температура $-T_{w}=1000 \mathrm{~K}$. На рис. 1 наведено результати визначення температурного профілю $T(r)$ такої дуги, отримані з розв'язку в одновимірному наближенні рівняння (40) балансу енергї для циліндричної дуги, стабілізованої стінками, та відповідний розподіл концентрації електронів $N_{e}(r)$.

Критеріальні оцінки умов відхилення від рівноважного стану плазми в такій дузі внаслідок перенесення випромінювання резонансної лінії 327,3 нм, нижнім рівнем переходу якої є основний рівень атома

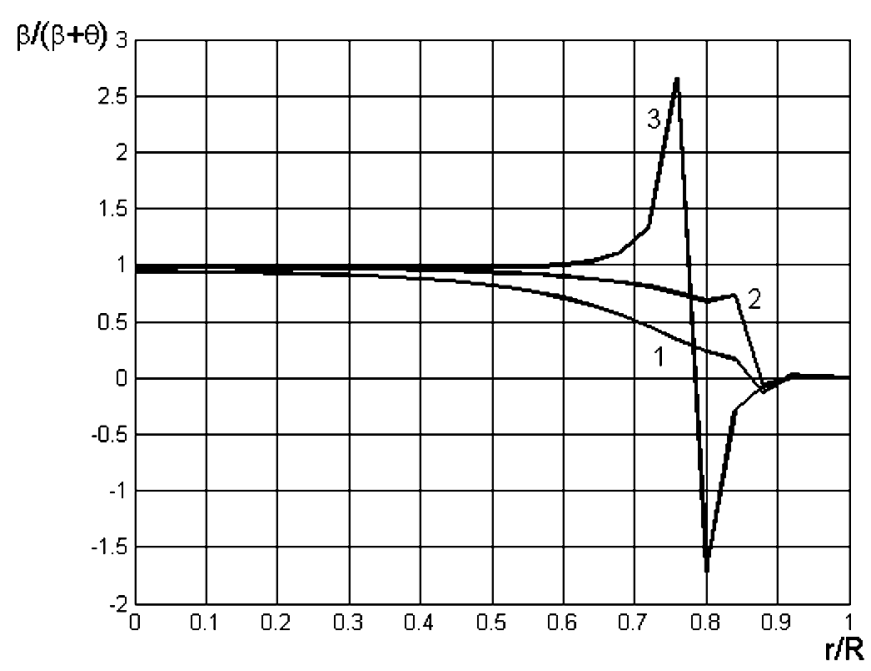

Рис. 2. Критеріальні оцінки умов відхилення від рівноважного стану плазми внаслідок перенесення випромінювання резонансної лінії 327,3 нм в електричній дузі з вмістом міді: $x_{\mathrm{Cu}}=$ 0,1\% (крива 1); 1\% (крива 2) і 10\% (крива 3)

міді, наведено на рис. 2. 3 них випливає (крива 2), що параметр $\beta(r) /[\theta(r)+\beta(r)]$ для цієї лінї демонструє різку еволюцію вздовж радіуса дуги. Зокрема, в осьовій області дуги він близький до одиниці, що свідчить про те, що якщо тут і є радіаційні ефекти, то вони сприяють підтриманню стану ЛТР у плазмі. Навпаки - у периферійній області дуги він набуває від'ємного, практично нульового значення. Останнє свідчить про те, що в цій області чинник радіаційного впливу, поданий доданком у знаменнику, стає переважаючим. Це вказує на те, що тут слід очікувати значного поглинання резонансних спектральних ліній, що в результаті приводить до відхилення від $\operatorname{ЛTP~}[24,25]$.

Для уточнення характеру переходу між згаданими вище областями (для $r / R=0,8-0,9$ ) було виконано варіювання значення вмісту міді в такій дузі; криві 1 i 3 на рис. 2 відповідають значенням $x_{\mathrm{Cu}}=0,1 \%$ і $10 \%$. $\mathrm{У}$ першому випадку це супроводжується зменшенням концентрації електронів на осі дуги $N_{e}(r=0)$ до $0,7 \cdot 10^{15} \mathrm{~cm}^{-3}$, а в другому - ï зростанням до $6,8 \cdot 10^{15}$ $\mathrm{cm}^{-3}$ (у такому варіанті задача не $є$ повністю самоузгодженою, оскільки температурний профіль для дуги, поданий на рис. 1, вважався незмінним). Відповідно змінювались заселеності збуджених рівнів атома міді. Характер переходу між цими областями для $x_{\mathrm{Cu}}=10 \%$ свідчить про те, що в області $r / R \approx 0,8$ $\epsilon$ компенсація ефектів втрат та поглинання випромінювання. Цьому відповідає нульове значення знамен- 
ника у параметрі $\beta(r) /[\theta(r)+\beta(r)]$ або перехід через плюс-мінус "нескінченність" самого цього параметра.

На відміну від цього для резонансної лінії атома міді 510,5 нм, нижній рівень спектрального переходу якої є метастабільним, параметр $\beta(r) /[\theta(r)+\beta(r)]$ змінюється плавно в межах від 0,8 при $r / R=0$ до нульового значення при $r / R=0,9$. Таким чином, результат розрахунку для цієї лінії не демонструє наявність області істотного поглинання спектральної лінії, хоча цей ефект спостерігався експериментально [5, 9]. Вочевидь, це пов'язано з прийнятими при постановці задачі спрощеннями стосовно сталого значення заселеності резонансного рівня уздовж радіуса дуги, що приводить зрештою до часткової втрати чутливості критеріального підходу в цьому варіанті. Можна очікувати, що вона може бути поліпшеною при відмові від цього наближення, проте це істотно ускладнить завдання.

Отримані результати відкривають можливість для проведення детальних розрахунків параметрів нерівноважної плазми з урахуванням процесів перенесення випромінювання зі включенням у модель кінетики заселення метастабільних і резонансних рівнів.

\section{6. Висновки}

У роботі виконано попередні розрахунки, що дозволяють принципово оцінити роль процесів випромінювання у відхиленні стану плазми від рівноважного. Оскільки ці розрахунки достатньо складні, то розв'язок задачі отримано у варіанті критерію застосовності ЛТР з урахуванням ролі процесів перенесення випромінювання у плазмі та його втрат. Така постановка дещо спрощує задачу, оскільки дозволяє обмежитись припущенням про рівноважний стан плазми при іiї розв'язку.

Результати роботи беззаперечно свідчать про те, що плазма у значній частині об'єму розрядного каналу атмосферної електричної дуги між плавкими мідними електродами є нерівноважною. Характер цієї нерівноважності відповідає перезаселенню резонансних рівнів плазмоутворюючих атомів на периферії каналу дуги внаслідок поглинання тут резонансного випромінювання з гарячої області дуги в їі приосьовій області.

Отримані результати вказують на неправомірність широкозастосовуваного припущення наявності ЛТР у плазмі електричних дуг з плавкими електродами.

Роботу виконано за підтримки НАН України (проект 44-11 НАНУ-РФФД).
1. В. Филькенбург, Г. Меккер, Электрические дуги и термическая плазма (ИЛ, Москва, 1961).

2. Г. Николис, И. Пригожин, Познание сложного (Мир, Москва, 1990).

3. И. Пригожин, Д. Кондепуди, Современная термодинамика. От тепловых двигателей до диссипативных структур (Мир, Москва, 2002).

4. Л.М. Биберман, В.С. Воробьев, И.Т. Якубов, Кинетика неравновесной низкотемпературной плазмы (Наука, Москва, 1982).

5. В.А. Жовтянский Физические свойства плотной низкотемпературной неоднородной плазмы (Дис... д-ра физ.-мат. наук: 01.04.08, Киев, 1999).

6. А.Н. Лагарьков, ТВТ 4, 305 (1966).

7. Л.М. Биберман, ДАН СССР 59, 659 (1948).

8. Спектроскопия газоразрядной плазмы, под ред. С.Э. Фриша (Наука, Москва, 1970).

9. И.Л. Бабич, А.Н. Веклич, В.А. Жовтянский, ЖПС 51, 571 (1989).

10. Г. Грим, Спектроскопия плазмы (Атомиздат, Москва, 1969).

11. В.А. Жовтянский, В.Н. Патриюк, Сб. трудов IV Meждунар. симпозиума по теоретической и прикладной плазмохимии (Иваново, 2005), 2.

12. Yu.I. Lelyukh and V.A. Zhovtyansky, in Proceedings of the 5-th Interantional Conference on Plasma Physics and Plasma Technology (NASB, Minsk, 2006), Vol. 1, p. 173.

13. В.А. Жовтянський, УФЖ 53, 488 (2008).

14. В.Н. Очкин, Спектроскопия низкотемпературной плазмы (Физматлит, Москва, 2006).

15. R. Konjevic and N. Konjevic, Fizika 18, 327 (1986).

16. I.L. Babich, A.N. Veklich, and V.A. Zhovtyansky, in Proceedings of the 11-th European Sectional Conference on the Atomic and Molecular Physics of Ionized Gases (St. Petersburg, Russia, August 25-28, 1992), Vol. 16F, p. 184.

17. Г.А. Касабов, В.В. Елисеев, Спектроскопические табличы для низкотемпературной плазмы (Атомиздат, Москва, 1973).

18. В.А. Жовтянський, Ю.І. Лелюх, В.М. Патріюк, УФЖ 53, 765 (2008).

19. V.A. Zhovtyansky, A.B. Murphy, V.M. Patriyuk, and Yu.I. Lelyuh, in Proceedings of the 17-th International Conference on Gas Discharges and Their Applications, edited by J.E.Jones (Cardiff University, Cardiff, 2008), p. 569.

20. В.А. Жовтянский, Пром. теплотехника 29, 13 (2007).

21. Э.И. Григолюк, В.И. Шалашилин, Проблемы нелинейного деформирования: Метод продолжения решения по параметру в нелинейных задачах механики твердого деформированного тела (Наука, Москва, 1988). 
22. Э. Хайрер, С. Нерсетт, Г. Ваннер, Решение обыкновенных дифференииальных уравнений: Нежесткие задачи (Мир, Москва, 1990).

23. H. Abdelhakim, J.P. Dinguirard, and S. Vacquie, J. Phys. D 13, 1427 (1980).

24. V.A. Zhovtyansky, Yu.I. Lelyukh, and Ya.V. Tkachenko, in Proceedings of the 3-rd Central European Symposium on Plasma Chemistry (Kyiv National Univ., Kyiv, 2009), p. 61.

25. V.A. Zhovtyansky, Yu.I. Lelyukh, and Ya.V. Tkachenko, in Proceedings of the 18-th International Conference on Gas Discharges and Their Applications, edited by K.-D. Weltmann (INP, Greifswald, 2010), p. 218.

Одержано 08.06.11

\section{ВЛИЯНИЕ ПЕРЕНОСА \\ ИЗЛУЧЕНИЯ НА ОТКЛОНЕНИЕ \\ ОТ РАВНОВЕСНОГО СОСТОЯНИЯ \\ ПЛОТНОЙ ЭЛЕКТРОДУГОВОЙ \\ ПЛАЗМЫ: КРИТЕРИАЛЬНЫЙ ПОДХОД}

\section{В.А. Жовтянский, Ю.И. Лелюх, Я.В. Ткаченко}

$\mathrm{P}$ е $з$ ю м е

Принципиально оценена роль процессов излучения с учетом его переноса касательно отклонения от равновесного состояния плотной электродуговой плазмы. Задача рассмотрена на примере электрической дуги цилиндрической формы, стабилизированной стенкой. Решение получено в варианте критерия применимости предположения о локальном термодинамическом равновесии с учетом роли процессов переноса излуче- ния в плазме и его потерь. Данные численного моделирования доказывают наличие эффектов отклонения от равновесного распределения заселения между резонансными и основным энергетическими уровнями атомов меди в условиях, моделирующих состояние плазмы в атмосферной электрической дуге между плавкими медными электродами.

\section{EFFECT OF RADIATION TRANSFER ON A DEVIATION OF DENSE ELECTRIC-ARC PLASMA \\ FROM THE EQUILIBRIUM STATE: CRITERION APPROACH}

\section{V.A. Zhovtyansky, Yu.I. Lelyukh, Ya.V. Tkachenko}

Institute of Gas, Nat. Acad. of Sci. of Ukraine

(39, Degtyarivs'ka Str., 03113, Ukraine; e-mail: zhovt@ukr.net)

$\mathrm{S} u \mathrm{~m}$ m a r y

A principal role of radiation emission processes in deviations of the electric-arc plasma at the atmospheric pressure from a state of local thermodynamic equilibrium has been estimated, by taking the radiation transfer into account. The problem was considered using a cylindrical wall-stabilized electric arc as an example. The solution was obtained in the approximation of local thermodynamic equilibrium with regard for the processes of radiation transfer and radiation losses in plasma. The results of numerical simulation obtained for copper atoms under conditions that correspond to the state of plasma in the atmospheric electric arc between melting copper electrodes confirm the existence of deviations from the equilibrium distribution between the populations at the resonance and ground energy levels. 